Olga Kosińska iDhttps://orcid.org/0000-0002-5356-2053

Uniwersytet Jagielloński

e-mail: kosinskaolga@gmail.com

Otrzymano/Received: 15.09 .2020

Zaakceptowano/Accepted: 7.11.2020

Opublikowano/Published: 11.12.2020

\title{
Cień cyfrowy - „zacienione” elementy fandomów internetowych
}

\section{Abstract \\ Digital Shadow - "Shady" Elements of Internet Fandoms}

Contemporary socio-economic changes affect organizations and management. Management processes more and more often concern spheres and groups that go beyond the "traditional" understanding of the organization. Among them are online communities such as fandoms. Along with the process of organizing, the organizational shadow is emerging. Organizational shadow is defined as "a set of unacceptable features, tendencies, aspirations rejected in the process of socialization" (Kostera 2014, s. 23), the appearance and functioning of which is negated or hidden within the organization. Fandoms are governed by slightly different rules, often more variable and more difficult to identify than in formal organizations. That does not make them free from "shady" elements such as certain people, activities, features and values that do not match the current shape of the community. The article describes fandoms as new, informal organizational forms and subjects of management processes, and then identifies examples of the emergence of organizational shadow within them. These are three main causes of such a shadow manifestation - excessive control (e.g., of the forum moderator), undisclosed actions of administrators of the internet platform used by the group, as well as negligence (e.g., forgetting someone's contribution to the project). The conclusions indicate the need for a further, in-depth identification of the elements influencing the development of the shadow in non-standard organizational forms.

Keywords: fandom, shadow, control, oblivion, virtual community

Słowa kluczowe: fandom, cień, kontrola, zapomnienie, wspólnota wirtualna 
Będąc , „ciemną” stroną rzeczywistości, cień nierzadko wartościowany jest negatywnie - jako coś, co ukrywa, zakrywa, przechowuje elementy niechciane, niepożądane, wręcz odrzucane. $Z$ cienia wynurzają się koszmary i potwory, czai się tam to, czego człowiek oglądać nie chce - a przynajmniej tak traktowany jest on w obowiązującej obecnie w tej części świata tzw. kulturze zachodniej. Podejście to można odnaleźć (a może i zidentyfikować jako źródło upowszechnienia się) u Carla Gustawa Junga, u którego wśród omawianych archetypów występujących w kulturze znajduje się między innymi cień. Jako właściwe mu miejsce wskazuje się mroczną, demoniczną wręcz stronę osobowości człowieka, w której przechowywane jest wszystko to, co jego świadomość odrzuca, zatem ,jest to zestaw nieakceptowanych cech, skłonności, dążeń, odrzuconych w procesie socjalizacji” (Kostera 2014, s. 23). Cień jest w tej perspektywie elementem o tyle trudnym do akceptacji oraz pozytywnego przepracowania, że nie wiąże się w całości z indywidualnymi cechami osobowościowymi (proces samopoznania, choć długi i żmudny, jest w stanie wedle Junga pomóc w akceptacji własnych „ciemnych miejsc”), lecz pewną nieuświadomioną projekcją omawianych kwestii do świata zewnętrznego (Jung 1976).

Organizacje, funkcjonujące przecież w konkretnym społeczno-kulturowym otoczeniu, także podlegają procesowi wykształcania się cienia. Odróżnić należy przy tym sformalizowane jednostki organizacyjne, jasno wyodrębnione $\mathrm{z}$ otoczenia, od procesu organizowania, któremu mogą podlegać podmioty niesformalizowane, ale wykazujące wysoki poziom koordynacji działań zmierzających do wyznaczonego celu. W procesie organizowania może wystąpić wiele cech, wartości, elementów czy nawet grup ludzi, których obecność jest negowana i/lub ukrywana w codziennym funkcjonowaniu podmiotu. Co dodatkowo „zaciemnia” obraz, to fakt, że negatywne reperkusje takiego odepchnięcia często zostają odseparowane od samej jednostki i „przerzucone" na inną instytucję, sytuację czy osobę, zewnętrzną dla organizacji jako całości lub konkretnego zespołu (np. konkurencję, związki zawodowe, dostawców, rządzących, pracowników innego działu). Jest to nierzadko efekt prób stworzenia i narzucenia pozytywnego wizerunku organizacji, w którym nie ma miejsca na elementy nieidealne.

Silny i aktywny cień prowadzi do poczucia niepewności, niepokoju, braku energii do działania, a w dłuższym czasie może prowadzić do wybuchu w postaci przemocy i niedającej się kontrolować negatywnej energii (mobbing, tyranizowanie pracowników, akcje sabotażu ze strony zatrudnionych, gwałtowne protesty) (Kostera 2014, s. 23).

Jednocześnie poddawane takiemu spychaniu i ukrywaniu mogą być elementy, jak się wydaje, pozytywne - „przejawy życia i żywotności wymykające się spoza kontroli” (Kostera 2014, s. 23). Kluczowym pojęciem wydaje się tutaj właśnie kontrola - cień organizacyjny wynika w dużej mierze z (prób) nadmiernego nadzoru, nierzadko wykonywanego w dobrej wierze, lecz przynoszącego niespodziewane skutki. Cień 
nie powstaje bowiem zupełnie przypadkiem, jest z reguły efektem celowych działań, lecz nierzadko rezultatem nieprzewidzianym w pierwotnym planie. Cień ewoluuje w czasie, jego granice oraz zawartość zmieniają się w zależności od chwili, potrzeb, cech ważnych dla jednostki w konkretnym momencie.

Podobne przemiany można zaobserwować na gruncie zarządzania. W obliczu rozlicznych zmian w otoczeniu, jakie wpływają na organizacje w ostatnich latach, między innymi wzrost znaczenia elastyczności, jak również informacji oraz wiedzy, przeniesienie większości działań do sieci internetowej, zmiana kluczowych kompetencji pracowników, decentralizacja działalności (Grudzewski, Hejduk 2011), weryfikacji i przekształceniom poddawane są dotychczas obowiązujące paradygmaty zarządzania. Jak pisze Frederic Laloux:

Istnieje (...) poczucie, że wyczerpaliśmy już pomysły na sposoby zarządzania organizacjami do granic możliwości i tradycyjne recepty często wydają się być tylko częścią problemu, a nie jego rozwiązaniem (Laloux 2015, s. 13).

W ramach prób wypracowania nowych podejść w literaturze przedmiotu pojawiają się więc takie pojęcia, jak organizacje wirtualne (Warner, Witzel 2005), organizacje w ruchu, organizacje dynamiczne (Stańczyk, Sus-Januchowska 2005), organizacje sieciowe, smukłe, inteligentne, zwinne, uczące się, hetararchie etc. (Grudzewski, Hejduk 2011). Kluczowe dla samego pojęcia organizacji pozostają jej nastawienie na cel lub zestaw celów ustalonych do osiągnięcia oraz możliwość wyodrębnienia jej z otoczenia, jak również pewien stopień formalizacji (Mrówka 2013). Jednak w obliczu postępującej decentralizacji władzy (zarówno na poziomie dla organizacji wewnętrznym, jak i zewnętrznym), przy wciąż rozwijających się formach współpracy oraz działalności wirtualnej, a także coraz częstszym zastępowaniu organizacji przez projekty i zespoły (Mrówka 2013), coraz trudniej jest mówić o procesie organizowania zarezerwowanym jedynie dla usankcjonowanych, wyodrębnionych form organizacyjnych. Widoczne jest to zwłaszcza w sektorze kultury, gdzie już od jakiegoś czasu obserwowane jest przeniesienie ciężaru organizowania jej oraz uczestnictwa na inicjatywy oddolne, wirtualne, nierzadko pozbawione formalnej hierarchii, o charakterze projektowym, spontanicznym lub opartym na wielostronnej współpracy. Identyfikowana jest prywatyzacja oraz deinstytucjonalizacja uczestnictwa w kulturze (Bachórz i in. 2014), a także przeniesienie działalności do internetu, zwłaszcza w obecnej dobie ograniczeń związanych z koronawirusem (Ćwikła 2020).

Niemniej, jak pisze Laloux:

Zadania zarządzania - ustalanie kierunków i celów, planowanie, kierowanie, kontrolowanie i ocenianie - nie znikają. Nie są już tylko dłużej skoncentrowane w rolach zarządczych, odpowiedzialnych za te problemy (Laloux 2015, s. 167). 
Bez względu na to, czy można mówić o formalnej strukturze, hierarchii, wyodrębnieniu $\mathrm{z}$ otoczenia etc., występowanie procesów organizacyjnych niesie zatem ze sobą zdolność do wytwarzania i kumulowania cienia organizacyjnego. Jest on rezultatem przede wszystkim jednego z trzech typów działań występujących w organizacjach: przemocy, kontroli oraz zaniedbania. Celem niniejszego artykułu jest zatem przede wszystkim identyfikacja oraz opis „zacienionych” elementów powstających jako rezultat wymienionych powyżej trzech elementów we współczesnych, niestandardowych formach organizacyjnych na przykładzie fandomów internetowych. Fandom określić należy jako wirtualną wspólnotę, zogniskowaną wokół wspólnych zainteresowań oraz celów, do której przynależność nabywa się poprzez określenie samego siebie jako fana danego zjawiska kulturowego oraz po uznaniu za takiego przez innych fanów, a więc także po nawiązaniu pewnych relacji z innymi fanami (Peacey 2020). Sprawia to, że członkostwo w fandomie ma w sobie zawsze pewien element performatywny, a wspólnota ta pozbawiona jest jednoznacznego wyodrębnienia $\mathrm{z}$ otoczenia. Artykuł oparty jest na analizie literatury przedmiotu i składa się z dwóch zasadniczych części - w pierwszej z nich scharakteryzowano zjawisko współczesnego fandomu oraz wskazano na zagadnienia organizacyjne. W drugiej części na jego przykładzie wskazano na wyłanianie się cienia w niesformalizowanych procesach organizacyjnych w konsekwencji trzech typów działan - przemocy, kontroli oraz zaniedbania. Tekst zamyka podsumowanie rozważań oraz wskazanie znaczenia pogłębionych analiz w tym zakresie.

\section{Wirtualny fandom}

Źródeł wykształcania się cienia organizacyjnego można wskazać wiele - a istnieją także sytuacje, w których wydawać się może, że pojawił się sam, nieproszony, przez nikogo nienagabywany. Można wskazać, że wyłania się on w swojej organizacyjnej postaci pod wpływem trzech czynników - nadmiernej kontroli, zaniedbań lub przemocy. Elementy te występują nie tylko w zarejestrowanych przedsiębiorstwach, instytucjach publicznych czy organizacjach pozarządowych - są również właściwe dla form organizacyjnych przekraczających granice tradycyjnie rozumianych organizacji. W swojej książce na temat turkusowych organizacji, z złożenia wykraczających poza główne współczesne paradygmaty zarządzania i stawiających między innymi na samozarządzanie się zespołów, Laloux wskazuje na liczne przemiany, jakie wpłynęły na organizacje i wymuszają na nich dostosowanie się do zmian. Wśród nich ważne miejsce zajmuje internet, który znacząco wpłynął na przekształcenia w tym zakresie, umożliwiając organizowanie się ludzi w grupy czy społeczności. Takie wirtualne zgromadzenia mogą wydawać się pozbawione cech organizacji i często tak jest - jednakże wymienione wcześniej kluczowe elementy, tj. wspólny cel, 
możliwość wyodrębnienia z otoczenia oraz pewien stopień formalizacji, właściwe są także wspólnotom wirtualnym, w tym fandomom. Wspólnoty te są:

stowarzyszeniami ludzi, których nie łączy wymiar czasowy, przestrzenny albo inne okoliczności fizyczne lub materialne - pomijając cechy samych ludzi i wykorzystywanych przez nich mediów. Wspólnoty wirtualne powstają w środowiskach elektronicznych za pośrednictwem komunikacji zapośredniczonej. (...) są luźnymi związkami ludzi, które w każdej chwili mogą się rozpaść. (...) Wspólnoty wirtualne składają się z ludzi mających określone zainteresowania lub przejawiających wspólną aktywność (van Dijk 2010, s. 233).

Takie pozornie słabe powiązania są w stanie jednak wytworzyć trwałe, choć elastyczne, struktury organizacyjne, opierające się przede wszystkim na wielostronnych relacjach. Wzrost znaczenia współpracy, dzielenia się, wymiany, wspólnej produkcji, handlu, dystrybucji czy innych rodzajów kooperacji jest przedmiotem rozlicznych analiz z różnych dziedzin, a także wyłaniania się takich konstrukcji, jak gospodarka dzielenia się czy gospodarka współpracy (Rifkin 2016; Tapscott, Williams 2011). W kulturze zaobserwować można w tym zakresie fandomy. Ich członkowie - fani - to użytkownicy kultury, których „podstawowym wyróżnikiem jest zaangażowanie. Fan to ktoś, kto charakteryzuje się wielokrotnym odbiorem" (Siuda 2010, s. 74) danego tekstu kultury, „aktywnie wyraża [dla niego - przyp. O.K.] upodobanie, uznanie, zachwyt”, co nierzadko prowadzi do przyjęcia przez niego roli „wtórnego producenta" (Siuda 2010, s. 74). Fanem można być na różny sposób, w zależności od stopnia zaangażowania, który z kolei zależny jest od osobistej motywacji, odmiennej dla danego tekstu kultury, sytuacji czy rodzaju promowanej aktywności (Siuda 2010; Jakubowicz 2011). Jak pisze Małgorzata Lisowska-Magdziarz:

Współczesny fandom to zbiorowość ludzi połączonych splotem rozmaitych więzi i pokrewieństw kulturalnych, społecznych, politycznych, przestrzennych, osobistych, uczuciowych i organizacyjnych (...). Przede wszystkim jednak to wspólnota praktyk społecznych i komunikacyjnych (Lisowska-Magdziarz 2017, s. 5).

Zbiorowość ta jest wirtualną wspólnotą zaangażowanych indywidualistów, którzy gromadzą się wokół wspólnych zainteresowań, korzystając z możliwości, jakie dają media społecznościowe, by przepracowywać, nadpisywać, remiksować, uzupełniać i dzielić się twórczością oraz wiedzą dotyczącą łączącego ich tekstu kultury. Jest to społeczność poddawana ciągłym przekształceniom, o fluktuacyjnych granicach, które mają za zadanie zarówno włączanie, jak i wyłączanie zeń jednostek na wewnętrznie określonych zasadach. Jednocześnie stawanie się pełnoprawnym fanem pozostaje efektem określenia samego siebie jako takiego oraz uznania za fana przez wspólnotę. Tym samym grupy te niosą ze sobą duży potencjał tożsamościowy, stając się środowiskiem, w którym odbywają się procesy kształtujące jednostkę jako fana 
(Peacey 2020). Rozwój fandomów spowodował przesunięcie się ich członków z pola subkultury, będącej nierzadko w kontrze do producentów czy twórców oryginalnych dzieł, do pozycji ważnych, a czasem nawet głównych odbiorców (Siuda 2010).

Jak wskazuje Lisowska-Magdziarz, działalność fanowska zasadniczo odbywa się w ramach siedmiu dziedzin: powtarzalnego odbioru tekstu kultury (zarówno indywidualnie, jak i zbiorowo), jego komentowania i objaśniania, dzielenia się wiedzą na jego temat, twórczości własnej powstałej pod jego wpływem, organizowania i utrzymywania zgromadzonej wokół niego wspólnoty, tworzenia sieci komunikacyjnych na jej rzecz, jak również wewnętrznych rozważań i analiz (Lisowska-Magdziarz 2017). Nie oznacza to, że aby być fanem, należy wykazywać aktywność we wszystkich tych obszarach - stopień zaangażowania zależy od subiektywnych czynników, jak również ewoluuje w ramach samego fandomu. Fani wykorzystują media oraz dostępne im zasoby poprzez ich personalizację, dostosowanie do „własnych, prywatnych celów lub do działań zbiorowych" (Lisowska-Magdziarz 2017, s. 6). Należy jednak podkreślić, że w zdecydowanej większości przypadków fani nie oczekują za swoją działalność gratyfikacji finansowej, choć jednocześnie stają się coraz bardziej świadomi manipulacji oraz wykorzystywania ich twórczości przez koncerny medialne w celach zarobkowych (Lisowska-Magdziarz 2017; Kreft 2019).

Działalność $w$ fandomie związana jest więc zatem $\mathrm{z}$ wykształcaniem się grupy osób o podobnych zainteresowaniach, które nierzadko przekraczają granicę pomiędzy twórcą a odbiorcą, a przy tym gotowe są dzielić się swoją wiedzą stosunkowo bezinteresownie. Istnieją jednakże wewnętrzne zasady, ustalane przez poszczególne fandomy, których złamanie grozi czasem daleko posuniętym ostracyzmem i wykluczeniem. Ich wyuczenie się jest formą akulturacji w nowej grupie społecznej. Wymagana jest wiedza na temat terminologii charakterystycznej dla danej wspólnoty, reguł komunikacji, zasobu podstawowej wiedzy, jak również etykiety (Haughton 2020). Jest to zatem forma wspólnotowego, partycypacyjnego zarządzania grupą, która w pewnych wypadkach wytwarzać może swoiste elity wewnętrzne. Jednocześnie jednak bez tego typu kontroli wewnętrznej fandom mógłby pozostać (jeszcze bardziej) bezbronny wobec działalności zmierzającej do wykorzystania i/lub zdobycia finansowej gratyfikacji poprzez użycie wytworzonej wewnątrz grupy wiedzy czy twórczości (Kreft 2015; Lisowska-Magdziarz 2017).

Wydaje się, że interpretacja skali oraz roli, jaką fandomy odgrywają zarówno w życiu poszczególnych ich członków, jak i w skali społeczeństwa czy kultury, w dużej mierze zależy od ogólnego stosunku do możliwości (także potencjalnej zmiany), jakie niosą ze sobą wspólnoty, działania, wreszcie praca w przeważającej większości (a niekiedy i w całości) oparta na sieciach wirtualnych. Niekiedy wspólnota fandomu może stanowić środowisko, w którym jej uczestnicy nawiązują pozytywne relacje, rozwijają swoją kreatywność i stają się uzupełnieniem dla działalności zogniskowanej wokół głównego tekstu kultury oraz tworzą przestrzeń współpracy pozarynkowej. $\mathrm{Z}$ drugiej strony praca wykonywana $\mathrm{w}$ fandomach poddana jest niekiedy zasadom 
związanym ze stosunkami produkcji, w których to relacjach fani często znajdują się na przegranej pozycji w relacjach z firmami, platformami czy posiadaczami praw autorskich do głównego analizowanego tekstu kultury (Kreft 2015).

Fandomy są dobrym przykładem na niestandardowe formy organizacyjne, które - choć pozbawione wielu formalnych elementów - podlegają procesowi organizowania. Badania fandomów muzycznych przeprowadzone przez Jacqueline Haughton wskazują także, że fani określają swoje wspólnoty jako podmioty podlegające procesowi organizacji, przy czym za najważniejsze cechy organizowania uznane zostały dwa elementy: podzielane zainteresowania oraz wspólny cel lub zestaw celów (Haughton 2020). Te dwa kluczowe obszary wydają się wystarczające, by nawet jedynie intuicyjnie zwrócić się w stronę zagadnień związanych z organizowaniem. Wskazywany często w ramach tego typu wspólnot brak hierarchii, choć stanowi zarówno zaletę, jak i wadę (Jemielniak, Przegalińska 2020), nie wyklucza obecności jakiegoś typu władzy wewnętrznej oraz przywództwa. Nie jest ono z reguły nadane raz na zawsze - raczej, jak w wypadku Wikipedii, „odpowiedzialność przenosi się na struktury i role" (Jemielniak, Przegalińska 2020, s. 42). Brak hierarchii niekiedy powoduje wydłużenie się procesu podejmowania decyzji, każdy bowiem przedstawiciel ma równe prawo wypowiedzieć się w danej kwestii. Fandomy wymagają także przyjęcia określonej kultury organizacyjnej - zaakceptowania zestawu wartości, zasad i standardów zachowania, właściwych dla danej grupy (Lisowska-Magdziarz 2017). Członkowie fandomu $z$ łatwością przekraczają jego granice i przemieszczają się pomiędzy różnymi wspólnotami - jednakże najbardziej zaangażowana mniejszość tworzy pewien trzon, który pozwala na wyodrębnienie, na przykład, fanów Gry o tron od fanów serialu Mad Men, nawet jeśli niektórzy użytkownicy są członkami jednej i drugiej grupy. Na wewnętrzną strukturę fandomu wpływają zasady i wymagania stawiane zarówno przez narzędzia technologiczne, jakimi posługują się członkowie, jak i otoczenie, w którym się komunikują.

W odróżnieniu od sformalizowanych przedsięwzięć społecznych (...), [fandomy - przyp. O.K.] nie mają prawnie zalegalizowanego statusu, procedur przyjmowania członków (choć rejestracja na platformach publikacyjnych daje dostęp do pewnych przywilejów), zarejestrowanych nazw czy logotypów. Nie wymagają też od swoich członków wyłączności, wykonywania ściśle wskazanych obowiązków czy permanentnego zaangażowania, opartego na umowie regulującej wzajemne zobowiązania (Lisowska-Magdziarz 2017, s. 128).

Cele działalności fanów nie stanowią zawsze jasno ustalonego z góry zwieńczenia konkretnego projektu (choć i takie sytuacje się zdarzają), lecz często są pewną mniej lub bardziej wyrażalną siecią powiązań oraz praktyk, wynikających niejako „samo przez się” z przynależności do fandomu. Wyróżnić należy tu także, podobnie jak w sformalizowanych organizacjach, cele indywidualne oraz cele wspólnotowe, które często, choć nie zawsze, się pokrywają. Podsumowując, „chodzi o połączenie 
odbioru ulubionego tekstu z komunikacją z innymi, wspólną pracą - wytwarzaniem wiedzy, prowadzeniem ciągłej kreatywnej konwersacji (...) wokół tych czynności” (Lisowska-Magdziarz 2017, s. 28).

Wspólnoty wirtualne, takie jak fandomy, organizują się i wyznaczają swoje własne, wewnętrzne ograniczenia, zasady, standardy zachowania. Uprawnione są także do nakładania kar i ograniczeń względem osób, które reguł tych nie przestrzegają. Na swój sposób może wydawać się, że fandom się samooczyszcza - w wyniku nierzadko nie do końca sprecyzowanego ciągu działań członkowie wykraczający poza ogólnie przyjęte granice zostają, zgodnie z przyjętymi zasadami, ze społeczności wykluczeni. Po części rzeczywiście tak jest - jednak jak każda forma organizacyjna, także fandomy niosą ze sobą sporą dawkę cienia, w dodatku w nieco innym kształcie niż w wypadku chociażby przedsiębiorstw, co związane jest w dużej mierze $z$ jego całkowicie internetowym charakterem. Wirtualny cień sprawia czasem wrażanie bycia bardziej transparentnym i łatwiejszym do identyfikacji niż w wypadku organizacji funkcjonujących w większym stopniu w świecie offline - wydaje się to jednak tylko pozornym ułatwieniem dla jego integracji bądź przeciwdziałania mu. W gąszczu połączeń, które powstają wewnątrz każdego fandomu, działania prowadzące do wykształcenia się cienia lub zepchnięcia jakichś zjawisk bądź osób w cień mogą pozostać niezauważone przez pozostałych członków wspólnoty, a tym samym utrudnić możliwość przeciwdziałania. Nie oznacza to, że w wypadku organizacji działających offline wszystkie tego typu czynności są identyfikowalne i jasne dla każdego uczestnika - jednak w wypadku nieustannie fluktuujących, zmieniających swój skład, niekiedy wykształcających chwilowe hierarchie oraz stosunkowo otwartych fandomów ukrycie, a także zwyczajne niezauważenie konkretnych procesów wydaje się jeszcze prostsze.

\section{W internetowym cieniu}

Nim wskazane zostaną przykłady cienia organizacyjnego, należy poczynić jedno zastrzeżenie. Poniższa analiza nie podejmuje się oceny działalności samych fandomów. Nie chodzi bowiem o stwierdzenie, czy zasady rządzące grupą są zgodne z taką czy inną hierarchią wartości, lecz o to, czy, a jeśli tak, to jakie elementy nieakceptowane są przez daną grupę i odrzucane przez nią w procesie akulturacji oraz socjalizacji. Chociażby ocena takich grup współpracujących wirtualnie jak Anonymous jest różna, a niektóre przejawy ich działalności kontrowersyjne. Ta grupa haktywistyczna wywodzi się z forum 4chan, serwisu znanego ze swojej orientacji prawicowej i altprawicowej, a podejmowane przez nich akcje protestacyjne i działania oceniane są odmiennie w zależności od indywidualnych przekonań. Podobne kontrowersje dotyczą Wikileaks, organizacji medialnej ujawniającej utajnione informacje. Ponownie, działania samego portalu, jak i jego założyciela Juliana Assange’a (niekiedy 
trudno jest te dwie płaszczyzny od siebie oddzielić) wywołują różne reakcje (Sorell 2015). Jednak istotą identyfikacji cienia nie jest ocena jawnych działań organizacji czy społeczności, lecz właśnie przyjrzenie się temu, co ukryte - a widoczne nierzadko znacznie łatwiej dla osób z zewnątrz niż członków danej grupy.

W większości organizacji nieprzestrzeganie ustalonego zestawu zasad i wartości, przejawianie odmiennych od ustalonego wzorca skłonności czy cech wiąże się z jakiegoś rodzaju karą. Chciałoby się może powiedzieć, że tak nie jest - że organizacje stają się tolerancyjne, otwarte, elastyczne, że skłonne są wchłonąć i dopasować się do wcześniej nieobecnych w ich wnętrzu elementów, o ile tylko obie strony są na to gotowe. Jednak tego typu procesy w szerokiej skali zachodzą stosunkowo rzadko, zwłaszcza w przestrzeni tak bogatej we wrażliwe elementy, o dalece subiektywnie nadawanej wartości jak kultura. Wypowiedzenie się na temat obejrzanego niedawno serialu czy przeczytanej książki, zwłaszcza w świecie stosunkowo powszechnego dostępu do internetu, samo w sobie nie stanowi trudności - teoretycznie nie trzeba być ekspertem od kina japońskiego, by wyrazić swoją opinię na temat filmów Akiry Kurosawy. Powoduje to czasem wiele sporów, kłótni, wyzwisk i innych sytuacji, w których brak zgody jednej strony na przyjęty przez drugą wzorzec jest przez tę ostatnią potępiany oraz negowany. Można nazwać to ciemną stroną kultury - nie jest to jednak tożsame $\mathrm{z}$ cieniem.

Jak już wspomniano, cień organizacyjny często jest wynikiem nadmiernej kontroli, jak również zaniedbań czy przemocy. Podobnie jak w wypadku sformalizowanych organizacji, tak i we fluktuacyjnej wirtualnej wspólnocie ustalane są

wewnętrzne normy i zasady, wypracowywane wspólnie w procesie jej budowania i powstrzymywania. Towarzyszą im określone, rozpoznawalne w fandomie symboliczne nagrody za ich przestrzeganie oraz kary za łamanie (Lisowska-Magdziarz 2017, s. 29).

Jeśli kara za przekroczenie ustalonych granic jest otwarcie wyrażana i decydujący się na taką działalność członek wspólnoty wie, co go czeka w danym wypadku, nie może być mowy o cieniu. W ramach fandomów pojawiają się niekiedy jednostki elitarne (np. takie, które organizują spotkania, inicjują projekty czy są popularne, a tym samym posiadają pewien autorytet wewnątrz grupy), których zdanie staje się decydujące w określonych sytuacjach, chociażby kontrolowania realizacji określonej kampanii (Haughton 2020). Inna sytuacja pojawia się jednak, gdy wdrażane zostają dodatkowe wymagania w sposób utajniony bądź wprowadzane są kary, o których członkowie nie mieli pojęcia. Pewna wpływowa mniejszość podejmuje we własnym gronie decyzję o nowych obowiązujących zasadach, eliminujących wcześniej akceptowane cechy czy rodzaje działalności. Moderator(-ka) forum może podjąć autonomiczną, niejasną co do przyczyn dla pozostałych osób decyzję o nieopublikowaniu czyjegoś materiału fanowskiego (opowiadania, komiksu, rysunku etc.) lub zablokowaniu wyświetlenia postów danej osoby. Fandom nierzadko przedstawiany 
jest jako miejsce, gdzie wyrazić siebie oraz odnaleźć wspólnotę mogą osoby marginalizowane w świecie offline - ze względu na swoją orientację seksualną, rasę, zamożność, płeć etc. Marginalizacja zachodzi jednak czasem także w jego ramach, a niepoddające się przyjętemu etosowi jednostki poddawane są przemocy symbolicznej. Istnieje pewien wzorzec „dobrego” czy „prawdziwego fana”, którego nieprzestrzeganie wiązać się może z brakiem akceptacji i odsunięciem. Jeśli więc dążenia poszczególnych członków grupy nie zgadzają się z ustalonym kanonem, niepasujące doń elementy zostają przemocą wyrzucone i ukryte, co niekiedy siłą rzeczy sprawia, że przejawiające takie skłonności jednostki zostają outsiderami.

$\mathrm{Z}$ drugiej strony czasem elementy zacienione $\mathrm{w}$ fandomie nie są do końca związane z tworzącymi go osobami, ale z technologią, której używają. $Z$ założenia niematerialne korzyści płynące ze współpracy, działalności podejmowanej przez pasjonatów na rzecz wybranych przez nich elementów otoczenia bywają wykorzystywane przez międzynarodowe korporacje w celach gromadzenia zysków. Tego typu ukryte efekty działalności fandomu stanowią niejako niezależny od niego cień - nikt do końca nie jest w stanie przewidzieć, kto i w jaki sposób może próbować wyeksploatować daną aktywność czy zasób. Teoretycznie najprawdopodobniej każdy świadomy użytkownik internetu wie, że za znaczną część tego, co ogląda, co jest sugerowane jako potencjalnie atrakcyjne, za liczbę wyświetleń i/lub osób, do których dana treść dotrze, odpowiedzialne są algorytmy. W teorii zdaje sobie sprawę z zagrożeń dla własnej prywatności, jakie niesie ze sobą aktywność na publicznych portalach. To, czego jednak nierzadko nie wie lub nie myśli o tym w codziennych działaniach, to skala tej działalności. Do jakiegoś stopnia z pewnością użytkownicy rozumieją, że ich dane osobowe są przetwarzane i wykorzystywane poza ich zasięgiem lub że ktoś może czerpać korzyści materialne z bezinteresownie wykonanej pracy kogoś innego, tworząc drugi rodzaj fandomowego cienia organizacyjnego. Cień ten wynika z ogromu kontroli, która sprawowana jest nie tylko w stosunku do członków fandomu - lecz w tym wypadku można mówić o ukrytych działaniach związanych z zajmowaną przez społeczność przestrzenią, która jest eksploatowana często bez wiedzy jej użytkowników. Wykorzystanie to często jest lepiej widoczne z perspektywy osoby w fandom niezaangażowanej, dla której rzeczywistość gromadzenia danych przez międzynarodowe korporacje, podejmowania dodatkowych działań w celu zwiększenia kontroli społecznej, wspierania tworzenia „baniek informacyjnych" (Pariser 2012) czy promowania określonych postaw poprzez zwiększenie ich widzialności (Kreft 2019) jest bardziej widoczna. Jak zauważa Astra Taylor, pojawienie się internetu i wszystkich zmian, jakie wraz z jego upowszechnieniem się występują, nie wywołało rewolucyjnego spłaszczenia i demokratyzacji dostępu do władzy. Nastąpiło raczej jej przesunięcie (wraz z kumulowaniem bogactwa), a wręcz centralizacja w rękach właścicieli platform, na których ludzie tworzą, konsumują treści oraz nawiązują relacje (Taylor 2014). Skala tych działań jest w większości ukryta przed szeregowym użytkownikiem i choć zwiększa się liczba przedsięwzięć 
uświadamiających w tym zakresie, wciąż istnieje gros elementów pozostających w zacienionej przybudówce, w którą wyposażona jest każda platforma i każda internetowa społeczność. Z jednej strony można więc mówić na przykład o używaniu informacji związanych $\mathrm{z}$ uczestnictwem $\mathrm{w}$ fandomie do lepszego dopasowywania reklam pojawiających się na Facebooku, by więcej na nich zarabiać. Z drugiej pojawia się skomplikowane zagadnienie praw autorskich do twórczości fanowskiej i traktowanie jej przez niektóre wpływowe osoby (jak chociażby Elona Muska) jako powszechnie dostępnej do dowolnego, bezpłatnego użycia, nawet bez konieczności podania autora(-ki) oryginalnego dzieła (Plunkett 2019). Tego typu działania powodują, że różnego typu kwestie (jak właśnie praw autorskich czy możliwości zarobku na twórczości fanowskiej) spychane są do cienia przez siły od fanów w dużej mierze niezależne, znacząco utrudniając lub nawet uniemożliwiając wypracowanie skutecznych mechanizmów włączania tych tematów do głównego nurtu dyskusji, wykraczającej poza sam fandom.

Ostatnią $\mathrm{z}$ analizowanych płaszczyzn pojawiania się cienia jest zagadnienie zaniedbań. Samo tworzenie określonego dobra wspólnego poprzez współpracę grupową nie jest zawsze i wszędzie głównym motywatorem do podjęcia działań. Ich wartość często znajduje się poza treścią danej inicjatywy - w możliwości powiększenia swoich wpływów, wypracowania swojego miejsca w fandomie czy nabycia możliwości decydowania. „Wartość jest tu raczej performatywna i oparta na doświadczeniu wspólnie osiągniętych efektów pracy przez osoby je tworzące i wykorzystujące" (Jemielniak, Przegalińska 2020, s. 57-58). Pamiętać jednocześnie należy, że raz uzyskany autorytet wewnątrz grupy wcale nie jest dany na zawsze - jeśli ktoś przestaje być aktywnym uczestnikiem, jej/jego pozycja zostaje mocno osłabiona. W konsekwencji największą wartość często ma sama aktywność, a nie jej rezultaty. Tym samym zepchnięciem kogoś do cienia staje się zapomnienie o którymś z członków. Czym innym jest samodzielne wyłączenie się z danej działalności czy projektu - możliwość takiego przechodzenia między trybami aktywności i nieaktywności jest wpisana w naturę otwartej współpracy czy produkcji partnerskiej (Jemielniak, Przegalińska 2020). Pozostaje jednak poza kontrolą danego członka fandomu symboliczne odstawienie go w kąt przez pozostałych. Zapominanie o kimś w trakcie podejmowania decyzji, rozdzielania zadań, wymieniania osób, które warto znać lub które są ważnymi ogniwami w danej wymianie, powoduje wykształcenie się „zacienionej osoby”. Nie jest ona pozbawiona praw członka grupy, nie jest zasadniczo zmarginalizowana - jest po prostu zapomniana i niezauważana, co w obliczu performatywnej wartości samej aktywności skazuje ją na niebyt. Zagadnienie to związane jest także z procesami wykształcania się wewnętrznych, właściwych poszczególnym fandomom hierarchii i/lub stosunków zależności. W obliczu braku formalnego nadzoru i organicznie kształtujących się relacji pojawiać się mogą jednostki o tendencjach autorytarnych, nieakceptujące określonych wzorów działań. W takim wypadku odsunięcie kogoś od danego projektu może być działaniem celowym (Haughton 2020) - często jednak 
przeniesienie danej osoby do cienia odbywa się niezauważone, poprzez zaniedbanie i zapomnienie o czyimś udziale.

\section{Cień bez g’anic}

Właściwy fandomom brak hierarchii oraz jasno określonych granic wpływa czasem na ich niekorzyść, wspierając wykształcanie się cienia. W wypadku tych wspólnot cień organizacyjny powstaje przede wszystkim w konsekwencji przemocy, nadmiernej kontroli oraz zapominania. Z jednej strony samozwańczy „przywódcy” potrafią wykluczyć wiele aktywności czy cech, które dotychczas były akceptowane, wytwarzając nieobecne dotychczas zakazy. Osoby niespełniające wymogów „idealnego fana” bywają odrzucane i upokarzane. Z drugiej strony cień powstaje w ramach relacji pomiędzy międzynarodowymi organizacjami medialno-technologicznymi a ich użytkownikami. Nie do końca jasne algorytmy rządzące poszczególnymi platformami gromadzą i przetwarzają dane poza zasięgiem oraz kontrolą osób, które je wyprodukowały. W ten sposób są w stanie chociażby zawiesić publikację lub upowszechnianie danego materiału, zablokować (czasowo lub na stałe ) czyjeś konto czy wymuszać dodatkowe zewnętrzne zasady funkcjonowania społeczności. Jednocześnie dzieje się to czasem także i bez większej pomocy oprogramowania w świecie wirtualnym, gdzie wiele historii pojawia się i umiera w ciągu minuty, niechciane skazanie kogoś na bycie zapomnianym ${ }^{1}$ odsuwa go w cień, z którego wydobycie się wymaga czasem sporego wysiłku.

Fandomy są jednymi z wielu niesformalizowanych grup o fluktuacyjnych granicach, które podlegają procesom organizowania. W obliczu współczesnych przemian wydaje się słusznym bliższe badanie tego typu wspólnot także z perspektywy zarządzania. Choć niekiedy trudno może być jednoznacznie wyodrębnić je z otoczenia, jak również wskazać (choćby i płaską) strukturę oraz wewnętrzną hierarchię, nie ulega wątpliwości, że odbywają się w ich ramach procesy charakterystyczne dla podmiotów, które określane są mianem organizacji. Pojawienie się tego typu wspólnot i pewne zatarcie granic definicyjnych pojęcia organizacji nie oznacza, że ta ostatnia skazana jest na zaniknięcie i wymarcie. Organizacje to jednostki, bez których nadal życie społeczne, ekonomiczne czy gospodarcze ludzkości nie może się w pełni realizować. Owszem, wskazać można - jak w wypadku fandomów czy Wikipedii na odmienne motywacje czy wzorce działania, które pojawiają się równolegle do rzeczywistości „tradycyjnych” organizacji. Zmiany w otoczeniu wywołują zmiany w samych podmiotach, toteż organizacje nie są tworami o sztywnych, raz na zawsze ustalonych granicach. Tym samym wydaje się zasadne stosowanie analiz,

1 Czym innym jest bowiem celowa i świadoma walka o prawo do bycia zapomnianym w internecie, a więc o usunięcie swoich danych z wyszukiwarek (Google otrzymało... 2020). 
które dotychczas dotyczyły przede wszystkim organizacji formalnych do ich mniej ustabilizowanych, lecz także podległych podobnym procesom niesformalizowanych odpowiedników. Wypychane, niechciane lub (celowo) zapominane elementy codzienności organizacyjnej występują zarówno w fandomach, jak i międzynarodowych korporacjach. Z racji znaczenia jednych i drugich dla życia ich uczestników ich identyfikacja jest równie ważna w obydwu przestrzeniach. Trzy kluczowe w tym wypadku obszary powstawania cienia organizacyjnego - przemoc, kontrola oraz zapomnienie - są w stanie w tym wypadku negatywnie wpłynąć nie tylko na obecność danej osoby w fandomie, ale (także ze względu na potencjał tożsamościowy tej wspólnoty (Taylor 2014)) na jej funkcjonowanie poza tą grupą społeczną.

\section{Bibliografia}

Bachórz A. i in. (2014), Punkty styczne: między kulturą a praktyka (nie)uczestnictwa, Gdańsk: Instytut Kultury Miejskiej, http://repozytorium.ikm.gda.pl/items/show/108 [odczyt: 8.09.2020].

Bértholo J. (2013), The Shadow in Project Management, „Procedia - Social and Behavioral Sciences", No. 74, s. 358-368.

Ćwikła M. (2020), Wademekum. Budowanie publiczności teatralnej w sieci, Wrocław, https:// kultura.uj.edu.pl/documents/18091666/29368678/WADEMEKUM_budowanie_publicznosci_teatralnej_w_sieci_MCwikla.pdf/f6fd1753-9272-48ce-b7a0-11b085646573 [odczyt: 14.09.2020].

Dijk J. van (2010), Społeczne aspekty nowych mediów. Analiza społeczeństwa sieci, , tłum. J. Konieczny, Warszawa: PWN.

Google otrzymało wnioski o usunięcie 2,4 miliona adresów URL. Trzy lata „Prawa do Bycia Zapomnianym", https://www.forbes.pl/technologie/prawo-do-bycia-zapomnianym-w- internecie-usuniecie-danych-z-wyszukiwarki/ln985gj [odczyt: 8.09.2020].

Grudzewski W.M., Hejduk I.K. (2011), Przedsiębiorstwo przyszłości. Zmiany paradygmatów zarządzania, „Master of Business Administration”, nr 1 (116), s. 95-111.

Haughton J. (2020), „They $F^{*}$ cking Own This Sh*t. They're Running It”: Are Music Fandoms Organizations?, https://scholarship.claremont.edu/cgi/viewcontent.cgi? article=2467\&co ntext=scripps_theses [odczyt: 10.09.2020].

Jakubowicz K. (2011), Nowa ekologia mediów. Konwergencja a metamorfoza, Warszawa: Poltext. Jemielniak D., Przegalińska A. (2020), Społeczeństwo współpracy, Warszawa: Wydawnictwo Naukowe Scholar.

Jung C.G. (1976), Cień, [w:] tegoż, Archetypy i symbole, tłum. J. Prokopiuk, Warszawa: Wydawnictwo Czytelnik, s. 63-68.

Kostera M. (2014), Studium przypadku a edukacja zarządzania, [w:] tejże (red.), O zarządzaniu historie niezwykłe. Studia przypadku z zarządzania humanistycznego, Warszawa: Wydawnictwo Difin, s. 15-31.

Kreft J. (2019), Władza algorytmów. U źródeł potęgi Google i Facebooka, Kraków: WUJ. 
Laloux F. (2015), Pracować inaczej. Nowatorski model organizacji inspirowany kolejnym etapem rozwoju ludzkiej świadomości, tłum. M. Konieczniak, Warszawa: Wydawnictwo Studio Emka.

Lisowska-Magdziarz M. (2017), Fandom dla początkujących. Część I. Społeczność i wiedza, Kraków: Instytut Dziennikarstwa, Mediów i Komunikacji Społecznej.

Mrówka R. (2013), Ewolucja modeli organizacji - od hierarchii do hiperarchii, [w:] tegoż, Organizacja hiperarchiczna - czynniki krępujące, geneza modelu, zarządzanie, Warszawa: Oficyna Wydawnicza SGH, s. 63-134, http://web.sgh.waw.pl/ rmrowka/Publikacje/Rafal\%20 Mrowka\%20-\%20Organizacja\%20hiperarchiczna.pdf [odczyt: 8.09.2020].

Pariser E. (2012), The Filter Bubble: What The Internet Is Hiding From You, London: Penguin Books.

Peacey B. (2020), You're the Only One Who Knows My True Identity: How Fandoms Create New Identities for Constructed Language Learners, https://open.library.ubc.ca/cIRcle/collections/ ubctheses/24/items/1.0394130 [odczyt: 10.09.2020].

Plunkett L. (2019), Elon Musk Doesn't Learn, Posts Uncredited Artwork, Deletes Tweet, https://kotaku.com/elon-musk-doesnt-learn-posts-uncredited-artwork-delet-1835562881 [odczyt: 10.09.2020].

Rifkin J. (2016), Społeczeństwo zerowych kosztów krańcowych, tłum. A.D. Kamińska, Warszawa: Wydawnictwo Studio Emka.

Siuda P. (2010), Jednostkowe aspekty bycia fanem, czyli w stronę nowego paradygmatu fan studies, „Kultura i Edukacja”, nr 4 (78), s. 74-94.

Sorell T. (2015), Human Rights and Hactivism: The Cases of Wikileaks and Anonymous, „Journal of Human Rights Practice", Vol. 7, Issue 3, s. 391-410.

Stańczyk S., Sus-Januchowska A. (2005), Organizacja przyszłości - wyjaśnienie podstawowych kategorii epistemologicznych, [w:] A. Stabryła (red.), Innowacyjność we współczesnych organizacjach, Kraków: Wydawnictwo AE, s. 237-246.

Tapscott D., Williams A.D. (2011), Makrowikinomia. Reset świata i biznesu, tłum. D. Bakalarz, Warszawa: Wydawnictwo Studio Emka.

Taylor A. (2014), The People's Platform: Taking Back Power and Culture in the Digital Age, London: Fourth Estate.

Warner M., Witzel M. (2005), Zarządzanie organizacją wirtualną, tłum. J. Kardaszewski, Kraków: Wydawnictwo Oficyna Ekonomiczna. 